\title{
Development Of Learning Devices Based On Constructivism Approach To Improve Mathematical Communication Skills Of Grade VIII Junior High School
}

\author{
$1^{\text {st }}$ Siti Zulaika \\ Department of Mathematics \\ Universitas Negeri Padang \\ Padang, Indonesia \\ zulaikasiti343@gmail.com
}

\author{
$2^{\text {nd }}$ Hendra Syarifuddin \\ Department of Mathematics \\ Universitas Negeri Padang \\ Padang, Indonesia \\ hendrasy@yahoo.com
}

\begin{abstract}
This research originated from the ability of mathematical communication and the activities of learners who have not developed optimally. Not developed ability of students is caused by lack of learning tools that can support the improvement of mathematical communication skills and the activities of learners. Learning tools will support the implementation of the learning process. The learning processes have not helped learners in developing their knowledge and finding their own principles/procedures of mathematics and convey the knowledge of mathematics it has. The purpose of this study was to reveal the development process and to produce lesson plan and student worksheet based on constructivism approach that is valid, practical and effective in improving the ability of mathematical communication and activity of students of grade VIII SMP. This type of research was development research using Plomp model consisting of three phases; they were initial investigation phase, prototype development phase, and assessment phase. In the development phase, the design and assessment of learning tools were done through the formative evaluation phase. The subjects of the study were grade VIII students of SMP Hang Tuah I Medan. The instruments used were lesson plan validation sheets, student worksheet validation sheets, interviews, observation sheets, teacher response questionnaires, student response questionnaires, and tests. The results of the analysis on the validation sheet of the lesson plan and student worksheet showed that the learning tools developed was valid. Learning tools were also practical based on the results of the analysis of teacher questionnaire responses, the questionnaire of learners' responses and observation sheet implementation of learning. Learning tools were also developed effectively to improve the mathematical communication skills of learners because $80 \%$ of learners got value above the KKM.
\end{abstract}

Keywords-Learning Devices, Mathematical Communication Skills Constructivism Approach.

\section{INTRODUCTION}

Mathematics has an important role in various aspects of life. Many problems and activities in daily life that must be solved by using mathematical sciences such as calculating the area of an area, calculating the speed of a vehicle even in trade used mathematical calculations and many others. The role of mathematics today is increasingly important because a lot of information is conveyed by people in mathematical languages such as tables, graphs, diagrams, equations and others. Mathematics is seen as a tool for finding solutions to various problems in everyday life.

Not only in various aspects of life, but mathematics also has a very important role in the world of education. This is evident in the world of education, mathematics is one of the subjects studied by students from elementary, secondary to tertiary education levels. Based on the law of the Republic of Indonesia No. 20 of 2003 concerning the National Education System Chapter X Article 37 is written, "the education curriculum for primary education and secondary education must contain mathematics education, civic education, language, natural sciences, social sciences, arts and culture, sports education, skills / vocational and local content ". This means that every student who is in elementary and secondary education must take mathematics lessons.

Each of these stages has abilities that must be mastered and possessed by students during the learning process of mathematics that has been established in the National Council of Teachers of Mathematics, namely: problem-solving ability, reasoning ability, communication capabilities (communications), connection capabilities, and representation capabilities (representations) [1]

There are eight objectives of mathematics learning. One of the goals of learning mathematics is to communicate ideas, reasoning and be able to compile mathematical evidence by using complete sentences, symbols, tables, diagrams, or other media to clarify circumstances and problems. Indicators of achievement of these skills include [2]:

a. Give reasons or proof of the truth of a statement. 
b. Predict and check the truth with conjecture.

c. Check the validity or correctness of an argument with induction reasoning.

d. Lower or prove the formula with deduction reasoning.

e. Predict and check the correctness of the conjecture.

Referring to the purpose of learning mathematics, communication is one of the goals of mathematics learning that must be achieved. This is because in the learning process students can convey their ideas or ideas. Through communication, ideas can be reflected, improved, discussed, and developed. The communication process also helps build meaning and emphasizes ideas in the process of learning mathematics. This shows that mathematical communication skills are necessary and important abilities to develop.

However, the current mathematical communication skills of students have not been in line with expectations. Based on the results of field observations and interviews with mathematics teachers at Hang Tuah I Middle School in Medan, it was known that the steps of the mathematics learning process carried out at the school were used as research sites, namely: 1) taught theory/ definition/formula; 2) given an example of a problem; 3) given practice questions. The learning process that is carried out has not been centered on students and students have not got enough space to construct their knowledge. Learning like this has not facilitated students to develop mathematical communication skills.

After making observations and interviews, researchers also tried to reveal the students' mathematical communication skills by giving 4 mathematics communication skills test questions to 39 students of grade VIII of Hang Tuah I Middle School in Medan. The student answer sheets are examined using the mathematical communication skills scoring rubric. The test results show that the communication skills of students experience problems.

Based on observations made in the grade room it was observed that only a few students who asked questions related to the material taught by the teacher, rarely seen the activeness of students in the process of learning mathematics and observed also that when the mathematics learning process takes place often found students are willing to solve mathematical problems given by the teacher but not willing to present the ideas used against the completion of the given mathematical problems. This shows that students' mathematical communication skills have not developed optimally.

The learning process of mathematics will be carried out well because it is supported by the mathematics learning tools used. Mathematics learning devices are arranged according to the needs of students. Based on the preliminary analysis, information was obtained that the mathematics learning tools used by the teacher were the lesson plan, lesson textbooks, and student worksheet.Through interviews with mathematics teachers at SMP Hang Tuah I Medan, information was obtained that the teacher had compiled the lesson plan quite well, only at the core learning activities did not appear to contain the steps or activities that directed students to use communication skills in daily life problems, so that the students have not been able to construct the knowledge they have. In the mathematics learning process, the teacher also uses student worksheet, the student worksheet used is the student worksheet that has been provided by the school, and not many teachers develop student worksheet.

Student worksheet that is used presents a description of the material and examples along with the solution. The student worksheet that is used can be complemented and developed in accordance with the needs of students, such as giving examples in the student worksheet that should be able to explore the knowledge of students in learning a material, not directly include the answers to these examples. So that students can build knowledge about the material that has been studied. Mathematics learning tools used (lesson plan and student worksheet) can still be developed again in order to facilitate students to improve mathematical communication skills.

One way to solve these problems is to develop the lesson plan and student worksheet based on constructivism approaches. Student worksheet based on constructivism approach is considered to motivate students to understand the meaning of the material they learn, namely by constructing knowledge independently to learn a material and get involved in learning.

The choice of the constructivism approach is driven by several arguments. First, in constructivism learning students themselves must find, understand, transform or even revise information or problems that exist to obtain problem-solving (solutions) [3]. This is in accordance with the definition of learning expressed by [4], namely "learning is the process of building or constructing understanding in accordance with the abilities possessed by someone". Second, the constructivism approach can facilitate students to build and find their own knowledge so that learning will be more interesting and enjoyable for. Third, in learning constructivism this "strategy of obtaining" takes precedence over how many students acquire and remember knowledge [3].

The selection of lesson plan development is because the lesson plan is a guide or guide for the implementation of the learning process that greatly determines the actions of teachers and students in achieving predetermined learning goals. The use of learning approaches, strategies, models, and methods is also illustrated in the lesson plan so that the development of lesson plan is the right step in designing learning processes that are able to make students as learning subjects no longer the object of learning. Researchers chose the development of student worksheet in this study because the preparation of student worksheet is very possible to direct the mindset of students in building knowledge and understanding their own mathematical concepts as well as to create independence of students in learning and finding knowledge so that it is expected to improve students' mathematical communication skills.

Lesson plan and student worksheet based on constructivism approach are expected to improve students 'mathematical communication skills because in constructivism learning knowledge is built in students' minds [5]. Student worksheet based on this constructivism 
approach is one of the tools that mathematics teachers can use to help students understand a mathematical concept and simultaneously improve students' mathematical communication skills. That ability will equip students in facing everyday problems. Student worksheet that is good in learning mathematics will provide the widest possible opportunity for students to develop their creativity in solving a problem.

The activities that will be compiled in the lesson plan and student worksheet in this study refer to the stages of learning constructivism approach, so as to improve students' mathematical communication skills. The design of the implementation of the learning system using the constructivism approach in this study follows the design proposed by as follows:

a. The situation, namely giving students an overview of the tasks that need to be completed so that students have the meaning of the learning experience that has been passed.

b. Grouping, at this stage students, is given the opportunity to interact with colleagues. Grouping depends very much on the situation or learning experience that students want to go through. Grouping can be done randomly or based on certain criteria (purposive).

c. Linkage, at this stage the linking component is carried out to connect the knowledge that is already possessed by students with new knowledge.

d. Questions, questions will bring up original ideas which are at the core of the constructivist learning approach. With the emergence of original ideas, students can build knowledge within themselves

e. Exhibition, this step provides opportunities for students to be able to show learning outcomes after following a learning experience.

f. Reflection, this step provides an opportunity for teachers and students to think critically about the learning experiences they have taken both personally and collectively. In addition, reflection also provides an opportunity for students to think about the application of the knowledge they already have.

Achievement of mathematical communication skills can be measured based on mathematical communication indicators. According to [6] identified that indicators of mathematical communication skills include:

a. Connecting real objects, images, and diagrams into mathematical ideas.

b. Explain ideas, situations, and mathematical relations, orally or in writing with real objects, images, graphics, and algebra.

c. State everyday events in a language or mathematical symbol.

d. Listen, discuss, and write about mathematics.

e. Read written mathematical presentations and compile relevant questions.

f. Conjuring, composing arguments, formulating definitions and generalizations.

Referring to some of the indicators that have been described, the indicators that will be examined by researchers are limited by three indicators, because of the three indicators that are considered sufficient to be a reference in the assessment of mathematical communication for students. The indicators of mathematical communication skills in this study are:

a. Explain ideas, situations, and mathematical relations, orally or in writing with real objects, images, graphics, and algebra.

b. State everyday events in a language or mathematical symbol.

c. Connecting real objects, images, and diagrams into mathematical ideas.

\section{METHODS}

Referring to the problem under study, the type of research used is a type of development research (Research and Development). According to [7] research and development methods (Research and Development) are research methods used to produce certain products and test the effectiveness of these products. Meanwhile, according to [8], research and development is a process or steps to develop a new product or perfect an existing product, which can be accounted for.

The product that will be produced in this study is a mathematics learning tool in the form of the lesson planand student worksheetbased on a constructivism approach to improve mathematical communication skills of VIII SMP students in Hang Tuah I Medan.

The model used in this study is an adaptation of the model developed by Tjeerd Plomp, which is stated as the Plomp research model. The Plomp research model is used because in this study a product will be produced, namely the lesson planand student worksheet based on a constructivist approach that is valid, practical and effective. According to Nieveen a material or product is said to be quality if it meets the quality aspects, namely: (1) validity, (2) practicality and (3) effectiveness (effectiveness); this development model consists of three stages [9]:

1. Preliminary research phase, which is the preparation stage consisting of needs analysis, curriculum analysis, student analysis and concept analysis.

2. The development phase (Prototyping phase), which is the process of designing and developing learning tools in stages by using formative evaluation to improve and revise the developed prototypes.

3. Assessment phase (Assessment phase), which is a semi summative evaluation process to conclude whether the final prototype or product is in accordance with the desired aspects of quality, namely validity, practicality, and effectiveness.

The stages in the development model are used to produce certain products and test the effectiveness of these products.

\section{RESULTS AND DISCUSSION}

\section{Initial Investigation Phase}

At this stage needs analysis, junior high school mathematics curriculum analysis for junior high school grade VII, analysis of students and concept analysis. The analysis results are described as follows.

a. Needs Analysis

This stage is carried out to gather information about what is needed by teachers and students so that it can 
improve the results of mathematics learning. This needs analysis was carried out through interviews with mathematics teachers of grade VIII SMP, observation of the implementation of learning activities, and giving questionnaires to students of grade VIII SMP.

Based on interviews conducted with junior high school mathematics teachers in grade VIII and grade room observations, information was obtained on the implementation of the mathematics learning process which tended to be the teacher who explained the whole subject matter of mathematics by lecturing. The teacher also directly gives important points to the material being studied. The steps of the mathematics learning process are as follows: 1) taught theory/ definition/formula; 2) given an example of a problem; 3) given practice questions. The information that is obtained next is about the activities of students in the process of learning mathematics. It can be seen that a few students who ask questions related to the material taught by the teacher and when the mathematics learning process takes place are often found that students are willing to solve mathematical problems given by the teacher but are not willing to present ideas used to solve the given mathematical problems.

The learning process of mathematics will be carried out well because it is supported by the mathematics learning tools used. The information obtained further is that it is known that the mathematics learning tools used by the teacher are the lesson plan, lesson textbooks, and student worksheets.

b. Curriculum Analysis

At this stage, an examination of the 2013 curriculum for the eighth-grade mathematics subjects in the odd semester was conducted. Analysis of the curriculum is carried out in two supporting aspects, namely Core Competence (KI) and Basic Competency (KD) in the material of the Two-Variable Linear Equation System. The curriculum analysis in question is an analysis of the indicators of achievement of competencies in SPLDV material which will then be developed into learning objectives that will be achieved at each meeting.

The basic competencies of the SPLDV material are KD 3.5 Explaining the system of linear equations of two variables and their solutions that are related to contextual problems.

c. Student Analysis

Student analysis is carried out to identify the characteristics of students in the eighth grade of junior high school. The aim of the researcher is to do this stage, which is to analyze the cognitive level of students, the way learners learn and the preferences of students on the colors, images, type of letters, and paper size in student worksheet.

For the purposes of this study, researchers took samples in grade VII-A in Medan Hang Tuah I. This data collection is done by giving a questionnaire and observing some students. From the results of the analysis obtained several characteristics of students. The first characteristic that is obtained is that the average students who sit in grade VIII are 11-14 years old. Based on Piaget's research, it was concluded that at that age cognitive development possessed by a child had been in the formal operation stage [10].

\section{d. Concept Analysis}

Concept analysis aims to determine the content and subject matter needed in the development of mathematics learning tools based on constructivism approaches. At this stage, activities are identified, detailed, and systematically arranged the main concepts that students will learn, namely the SPLDV material to achieve indicators of achievement of competence.

\section{The phase of the Development or Making of Prototype}

Based on needs analysis, curriculum analysis, concept analysis, and analysis of students, lesson planand student worksheet were designed based on constructivism approach which refers to the constructivism approach that is suitable to be applied in grade VIII in odd semesters. lesson planand student worksheet that have been designed are called prototypes I.

a. Making Lesson Planand Student Worksheet

The lesson plan is a plan that describes the procedures and organization of learning to achieve a predetermined basic competence. The lesson plan function is as a guide for teachers in delivering learning material. The lesson plan is systematically designed in accordance with the components of writing the lesson plan written in [11] concerning Process Standards. The designed learning activities refer to learning with a constructivism approach that is integrated with the use of student worksheet. Presentation of lesson plan identity, core competencies, basic competencies, indicators of competency achievement, learning objectives, teaching materials, time allocation, learning methods, learning activities, learning resources and assessments are almost the same as the lesson plan in general.

Student worksheet which is designed and developed refers to the characteristics of the constructivism approach. Student worksheet that is designed to help students to construct, find their own new knowledge related to learning material based on indicators of achievement of competence. The student worksheet is designed and developed for one semester, which is an odd semester consisting of five chapters of subject matter. The characteristics of student worksheet described are student worksheet chapter five with the material of the TwoVariable Linear Equation System (SPLDV), all chapters are designed with the same student worksheet is adjusted to the size of the student worksheet commonly used by students, namely the A4 size. Student worksheet presentation consists of student worksheet usage instructions, Basic Competencies (KD), indicators, learning objectives and time allocation.

b. Self Evaluation of Lesson Plan and Student Worksheet

Furthermore, the results of the design of the mathematics learning device based on the constructivism approach were evaluated by themselves before being discussed and validated with experts namely, educational technology experts, Indonesian language experts, and mathematics education experts. Self-evaluation is done by looking back at the results of the device design and correcting errors that are clearly visible on the device, such as the use of words, terms, punctuation, image placement, 
and legibility. Furthermore, there are several main aspects that are evaluated, namely: suitability of lesson plan elements, suitability of learning content/material, suitability of lesson plan and student worksheet with constructivism approach.

c. Validation of Experts (expert review) Lesson Plan and Student Worksheet

Test the validity of learning devices based on constructivist approaches validated by 5 validators. The experts who became validators came from 3 areas of expertise, namely 3 mathematics education lecturers, 1 education technology lecturer and 1 Indonesian lecturer. The results of the validity test of the lesson plan for each aspect by experts are very valid. Overall lesson plan developed has an average of 3.55 with a very valid category. So it can be concluded that the lesson plan based on this constructivism approach has been valid.

While the average validation of student worksheet as a whole is 3.43 with a very valid category. The average presentation aspect is 3.48 with a very valid category, the content feasibility aspect is 3.72 with a very valid category, this means that the presentation and suitability of student worksheet content based on constructivism approach can help students to construct their own knowledge and improve mathematical communication skills.

d. One-to-one Evaluation

Next is the one-to-one evaluation stage. In the evaluation process, one researcher observes and records the students' responses and questions about student worksheet. After the student worksheet is completed by the students, then the students are interviewed about the student worksheet.

One-to-one evaluation is done by asking 3 students to read, work on and give comments or suggestions about student worksheet. In the implementation process, three students are called alternately or one by one. The three students have different abilities, namely 1 high-ability person, 1 moderate-capable person and 1 low-ability person. e. Small Group Evaluation

Furthermore, student worksheet is tested in the small group evaluation stage (evaluation of small groups). The number of students needed is 6 students with different abilities, consisting of 2 students with high, medium and low abilities. Students are divided into three study groups, each group consisting of 2 people. Small group evaluations are held in six meetings.

The learning process carried out in the small group evaluation stage is that researchers teach using learning tools based on constructivism approaches that have been designed. The learning process in a setting resembles grade room learning. During the learning process takes place, observation is made of the difficulties experienced by students in the learning process and the suitability of the time used.

\section{Assessment Phase}

Field testsare carried out in the assessment phase. After being revised based on input on the small group evaluation, then the device was tested on a larger research subject, namely, grade VII-A of Hang Tuah Middle School I Medan as many as 40 students. Students are divided into 10 groups, each group consists of 4 students. The trial was conducted in 6 meetings. During the field test, the researchers were assisted by one mathematics teacher who taught in the grade and one observer.

a. Practicality Test

Schedule of learning implementation in the field test phase in accordance with the usual learning schedule. In the field test phase, learning is carried out according to the steps in the lesson plan. After learning is carried out using student worksheet until the sixth meeting, the teacher and students complete the practicality questionnaire. The practicality questionnaire is filled by the teacher aimed at getting information about the practicality of student worksheet based on the teacher's consideration.

Based on the results of the practicality questionnaire filled in by the teacher, the average practicality score of $90.13 \%$ is in very practical criteria. So it can be concluded that the lesson plan and student worksheet based on constructivism approach can be implemented and used properly by the teacher. The results of the student practice questionnaire obtained an average value of practicality is $87.47 \%$ on very practical criteria. This means that student worksheet based on constructivism approach can be used well by students in learning.

b. Effectiveness Test

The effectiveness of the use of student worksheet based on constructivism approach is seen in the activity and final test scores to see students' mathematical communication skills after all meetings are completed. The results of the data analysis results of students' mathematical communication skills test can be seen in the following table.

\begin{tabular}{|c|c|c|c|}
\hline & \multicolumn{2}{|c|}{ Completeness } & \multirow{2}{*}{ Total } \\
\cline { 2 - 3 } & $\begin{array}{c}\text { Complete } \\
(\geq 70)\end{array}$ & $\begin{array}{c}\text { Not } \\
\text { Complete } \\
(<70)\end{array}$ & \\
\hline $\begin{array}{c}\text { Total of } \\
\text { Student }\end{array}$ & 32 & 8 & 40 \\
\hline Percentage & $80 \%$ & $20 \%$ & $100 \%$ \\
\hline
\end{tabular}

From the table shows that the percentage of students who complete is $80 \%$ or $\geq 70 \%$. From observations of students' activities at each meeting, it was also known that the positive activity of students on average increased. So it can be concluded lesson plan and student worksheet based on the constructivism approach that has been developed have been effective to improve students' mathematical communication skills.

\section{CONCLUSIONS AND RECOMMENDATIONS}

Based on the results of data analysis that has been done can be concluded lesson plan and student worksheet based on the constructivism approach that has been developed are valid, practical, and effective to improve students' mathematical communication skills. Based on the above conclusions, the lesson plan and student worksheet based on constructivism approaches can be used as guidelines for teachers in implementing learning to improve mathematical communication skills and activities of students. 


\section{REFERENCES}

[1] NCTM, Principles and Standart for School Mathematics. USA: The National Council of Teacher of Mathematics, Inc, 2000.

[2] Peraturan Menteri Pendidikan dan Kebudayaan Nomor 58 tahun 2014 tentang Tujuan Pembelajaran Matematika. Jakarta, 2013.

[3] Marsitin, Retno, "Pendekatan Konstruktivisme pada Metode Diskusi Dalam Meningkatkan Prestasi Belajar Matematika Siswa SMP Muhammadiyah 3 Kepanjen Malang," Jurnal Inspirasi Pendidikan Universitas Kanjuruhan Malang, vol 3 no. 1, 2013.

[4] Sopamena, Patma, "Konstruktivisme dalam Pendidikan Matematika," Horizon Pendidikan," vol.4 no. 1, Juni 2009.

[5] Bodner, G.M, "Constructivism: A Theory of Knowledge," Journal of Chemical Education, vol. 63, pp. 873-878, 1986.
[6] Sumarmo, Utari, Pendidikan Karakter serta Pengembangan Berfikir dan Disposisi Matematik dalam Pembelajaran Matematika. Tersedia di http://utari-

sumarmo.dosen.stkipsiliwangi.ac.id/files/2015/09/Mak alah-Univ-di-NTT-Februari-2012.pdf, 2012.

[7] Sugiyono, Metodologi Penelitian Pendidikan Pendekatan Kuantitatif, Kualitatif dan R \& D. Bandung: Alfabeta, 2012.

[8] Sukmadinata, Syaodih N, Metode Penelitian Pendidikan. Bandung: PT Remaja Rosdakarya, 2008.

[9]

lomp, T. \& Nieveen, N. Educational Design Research, Part A: An Introduction. Netherlands Institute for Curriculum Development (SLO), Netherlands, 2013.

[10] Piaget, J., Genetic Epistemologi. New York: Columbia University Press, 1970.

[11] Peraturan Menteri Pendidikan dan Kebudayaan Nomor 22 tahun 2016 tentang Pedoman Pelaksanaan Pembelajaran. Jakarta, 2016. 